Sultan Qaboos University Journal of Arts \& Social Sciences

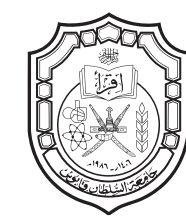

جامعة السلطان قابوس

\title{
New Englishes Norms: A Reality or an Intellectual Ideal?
}

\footnotetext{
Chandrik Balasubramanian

Associate Professor

Department of English Language and Literature

College of Arts and Social Sciences

Sultan Qaboos University, Oman chandribala@squ.edu.om
}

\author{
Adel AbuRadwan \\ Associate Professor \\ Department of English Language \\ and Literature \\ College of Arts and Social Sciences \\ Sultan Qaboos University, Oman \\ radwan@squ.edu.om
}




\title{
New Englishes Norms: A Reality or an Intellectual Ideal?
}

\author{
Chandrik Balasubramanian and Adel AbuRadwan
}

\section{Abstract:}

It is now widely accepted that English does not belong to the traditional native speaker countries such as the UK or the USA, and that English across the world has diversified and established roots in different parts of the world. Given this, studies have emerged, that focus on New Englishes being systems unto themselves, and not merely erroneous versions of more traditional "native" Englishes (Rajagopalan, 2012).

Scholars today are calling for descriptions of New Englishes to form the bases of New English handbooks, which, they claim, could serve as pedagogical models. Linguists like Lange (2011) and Kachru (1994) and literary figures such as Salman Rushdie alike have called for the recognition of New Englishes to be accepted and used in order to better reflect the global nature of the language

The aim of this study is to determine whether new international varieties of English are acceptable among language teachers. Specifically, the paper investigates how acceptable certain well-documented New Englishes structures are among English language professionals working at the tertiary level in the Arab world and North America. The results show that while participants are, in general, more tolerant of New English structures in students' spoken forms than in both students and their own written forms, they stated that they would not use any of the structures in their own writing. Results also show that the respondents' native language, specialization and educational qualifications are factors that impact their acceptance of these forms.

Keywords: new Englishes, tertiary classrooms, registers, attitudes.

\section{الإنجليزيات الحلديثة: واقع أم مثالية فكرية؟}

\author{
شاندرك بالاسبرامانيان و عادل رضوان
}

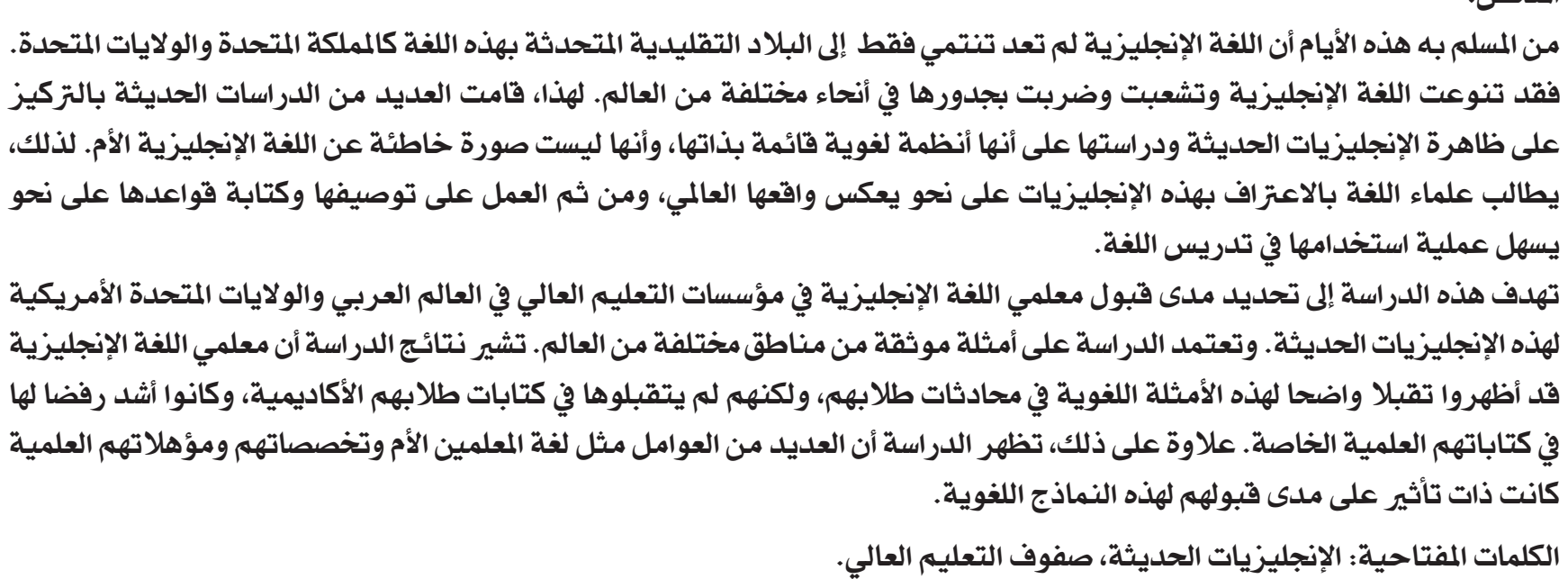




\section{Introduction}

The rapid spread of English and its rising status as a world language has been a subject of discussion in the fields of Applied Linguistics and dialectology for several years now, and accompanying this spread has been the emergence of several new varieties of English. These new varieties have variously been called Non-Native Varieties of English, New Englishes, NonNative Englishes, etc., demonstrating a recognition of the new varieties as legitimate systems unto themselves rather than erroneous forms of traditional "native" varieties. As Rajagopalan eloquently explains, the need for the name Englishes, itself "was first felt in the wake of the growing disenchantment with the now-outmoded idea of dividing the Anglophone world into so-called native speakers on the one side and everyone else on the other" (2012: 375). Jenkins (2003: 2) states that while "the English language was spoken in the mid sixteenth century only by a relatively small group of mother-tongue speakers born and bred within the shores of the British Isles, it is now spoken in almost every country of the world, with its majority speakers being those for whom it is not the first language". Further, According to Crystal (2003) English is spoken as an L1 and an L2 by five hundred and seventy-two million people in seventy-five territories. Today, as Crystal explains, "World English exists as a political and cultural reality" (Crystal, 2003: xii). In addition, as Schneider (2003: 233) explains, "present-day English as a global language is more than the world's predominant lingua franca - it is also a language which is currently growing roots in a great many countries and communities around the world, being appropriated by local speakers, and in that process it is diversifying and developing new dialects". What these newly diversified dialects look like, and how they are different from traditional native varieties of the language, has been a subject matter of inquiry for several decades.

Kachru (1994) first explained the spread of English in the world and the different roles it plays in different countries by suggesting that we think of three concentric circles: the Inner Circle, the Outer Circle, and the Expanding Circle. Kachru suggests that the Inner Circle includes countries where English is spoken as the primary language - countries like the UK and the USA, countries that are the traditional cultural and linguistic bases of English. The Outer Circle includes countries like India and Singapore, where English functions as an important second language; these outer circle countries are typically multilingual, and English also plays the role of common language of communication. The last circle, the Expanding Circle, includes countries like China and Russia, countries "which recognize the importance of English as an international language, though they do not have a history of colonization by members of the inner circle, nor have they given English any special administrative status" (Crystal, 2003: 60). Today, by many estimates, outer circle English speakers (300-500 million) far exceed inner circle speakers (320-380 million) (Crystal, 2003).

Scholars have for long discussed the importance of Kachru's model. For example, Canagarajah explains that the model "established the legitimacy of the new varieties of English in the outer circle, affirming their validity for these communities. The model thus pluralized the English language" (2013: 4). Kachru's model, therefore, advocates the rejection of English as a homogeneous language with one uniform grammatical system. Since Kachru first proposed his influential model, research on New Englishes has proliferated, and there are now studies on varieties as diverse as Tobagonian English (Youssef, 1995), on the one hand, to Phillipine English (Martin, 2014), on the other.

\section{Research on New Englishes}

The importance of the recognition, and indeed, the advocacy of these different and new varieties of English is, perhaps, best exemplified in a quote by Salman Rushdie in an article in The Times entitled The Empire Writes Back with a Vengeance. In this article, Rushdie claims that the English language "needs to be decolonized to be remade in other images, if those of us who use it from positions outside Anglo-Saxon culture are to be more than artistic Uncle Toms" (1982: 8). Since Kachru's description of the Concentric Circles in the 1960 s, the field has seen both a variety of models that do attempt to examine the new Englishes "in other images," and to account for the variation in International Englishes (for example, McArthur, 1998; Schneider, 2003, 2007) and numerous studies identifying characteristics of New Englishes. Thus, while earlier studies identified characteristic features of the New Englishes, with a primary purpose of determining how they were different from the traditional native varieties, later studies have gone much beyond, seeking, instead, to determine how the New Englishes work as systems unto themselves. Examples of earlier studies on New Englishes include for example, Bauer, (1989) on New Zealand English; Baumgardner, (1996), on Pakistani English; Gisborne, (2000), on Hong Kong English; and Bansal, (1976), Bakshi, (1991), and Hosali, 
(1991), on Indian English, to mention just a few. Later, larger-scale studies various international Englishes include Balasubramanian, (2009); Sedlatschek, (2009); Schilk, (2009); and Kirkpatrick, (2010).

With the emergence of book-length treatments of variation within new varieties such as the later studies mentioned above, a logical question that has arisen is whether any new variety of English can and should serve as an educational model, and this "requires us to think about who can claim the right of creative use of English in an era when NNESs are making English their own" (Jenkins, 2015: 26). Further, as Schneider (2009: 9) points out, this is particularly true of research originating in Asia, Africa, and North America, where he explains that "relatively more scholars than in Europe are concerned with issues of language policy, (and) pedagogy". Indeed, scholars today are calling for theoretical descriptions of New Englishes to form the bases of New English handbooks, which could serve as pedagogical models. Researchers like Mukherjee and Schilk (2009) and Lange $(2007 ; 2011)$ claim that one of the outcomes of descriptions of post-colonial Englishes is the handbooks and textbooks that are available and provide models for the language classroom today. Mukherjee and Schilk (2009: 8) explain that there are a number of "new emerging epicenters" that are developing (or have developed) into "potential normproviders and model varieties for smaller postcolonial Englishes in their immediate neighborhood." They describe Indian English as being one such norm-provider for the South Asian region. Erling (2005: 43), in also recognizing the importance of New English educational models, explains that it is important that "ELT professionals around the world move their practice away from an ideology that privileges L1 (inner circle) varieties". Seidelhofer (2004: 209) explains that there is currently "a state of delicate balance" between "the majority of the world's English users" who use different varieties of English and those who "control the norms of the language," largely traditional native speakers who use English in monolingual settings.

\section{Attitudes Towards New Englishes}

Attitudes towards New Englishes, however, seem to differ between scholars of New Englishes, on the one hand, and teaching practitioners and students, on the other. For example, based on her study of the attitudes of Chinese speakers towards native English, Wang (2016: 35) concludes that in EFL contexts like China, even today, "English language teaching and testing have been exclusively oriented toward native English". Similarly, Martin (2014), on Philippine English, explains that even though many Filipino scholars have indeed rejected the dominance of a traditionally native English such as American English, many remain ambivalent in their attitudes towards Philippine English, and particularly the place of Philippine English in the language classroom. Ren, Chen, and Lin (2015) explain from their study of 400 students in mainland China and Taiwan, that students, by and large still favored native speaker English. Another study on attitudes towards Indian English revealed that "listeners tend to hold negative attitudes towards speakers of non-standard English, and judge them unfavorably" (Hsu, 2016: 367). Based on his study of IELTS test takers' perceptions of World English structures in the IELTS test, Hamid's results, perhaps, best exemplify the non-researcher's stance towards New Englishes. He says of his test-takers that "while the majority of them supported WE in an abstract, ideological sense, they were against the inclusion of EE in the test for reasons related to maintaining standards, fairness, equality and test-taker interests" (2014: 263).

Given the contrasting attitudes towards New Englishes of scholars, on the one hand, and students and teaching practitioners, on the other, it seems that although the movement toward truly accepting different varieties of international Englishes as norm providing models seems ideal, and indeed, necessary, whether the challenging of the status of native speaker norms is indeed a reality, or it simply a politically correct idea propagated by the academic community remains to be seen. Erling's (2005: 40) theory about the need to "shape a new ideology for English language teaching (ELT) which more accurately reflects the global nature of the language and its diverse uses and users" is definitely valid. However, it is uncertain whether we are even close to moving away from the days of the "so-called native speaker unilaterally (and selfreassuringly) invoking authority to legislate over what is and what is not acceptable as "passable" English" (Rajagopalan, 2012: 380). It is important to question Milroy \& Milroy's claim that "the attitudes of linguists (professional scholars of language) have little or no effect on the general public, who continue to look at dictionaries, grammars, and handbooks as authorities on 'correct' usage" (Milroy \& Milroy, 1985: 6). What the attitudes of teaching professionals are towards World English structures is what this paper attempts to investigate. Specifically, a study such as this will contribute to the continued discussion on the place of 
New Englishes in the language classroom, particularly in EFL contexts.

\section{Research Questions}

1- What are English teachers' perceptions towards New English structures in a) their students' written academic work; b) their students' spoken academic work; c) their own written academic work?

2-Are there any differences between male and female teachers' attitudes towards New English structures?

3- Are there any differences between teachers' attitudes toward New English structures based on their own native languages?

4- Are there any differences between teachers' attitudes toward New English structures based on their specializations?

5- Are there any differences between teachers' attitudes toward New English structures based on their number of years of teaching experience?

6- Are there any differences between teachers' attitudes toward New English structures based on their own educational qualifications?

It is important to note here that as far as we know, teachers' attitudes toward New English structures have not been studied from the perspective of the influence of their native languages, specializations, years of teaching, or educational qualifications on their attitudes. These are areas that the current paper attempts to investigate, that could serve as a stepping stone for future research.

\section{Methodology}

A questionnaire (see Appendix A) containing 25 sentences, each containing a World English structure was constructed using Google forms and posted online. The World English structures chosen for the questionnaire all came from previous research on the particular international English. The source of these items is provided in parentheses below. The items in the questionnaire and specific varieties of English they come from include the following:

1- Indian English (Balasubramanian, 2009)

a- He is going there, isn't it?

b- It is costing too much money.

c- I am having a pain in my stomach.

$\mathrm{d}-\mathrm{I}$ have been there last year.

e- It has lot of layers.

f- Do you know what will she say?

g- Problems are there with every party.

h- It's a good environment, good friends, and good environment also. i- He has parked wrongly. He has parked straight before I came.

2- Irish English (Melchers \& Shaw, 2003)

a- If I had the doing of it again, I'd do it different.

b- I was knowing your face.

3- Chicano English (Williams, 2005)

a- We got in our bikes and rode down the hill.

b- The ring of my fiancée was expensive.

c-I didn't do nothing.

4- Singapore English (Mesthrie et al., 2012)

a- One of the lecturer told me to see you.

b- What you doing on weekend? Want to go out?

c- But the grandsons, they know how to speak English.

5- Philippine English (Bautista, 2005)

a- That's one of the related problem we will be discuss.

b- But a survey done by Pulse Asia shows majority of their respondents want President Estrada.

6- South African Indian English (Mesthrie, 1992)

a- Although you are away, but you do not forget.

b- The guests what you invited are not here yet.

c-I have seen you already.

\section{7- Regional American English (Grieve, 2015) \\ a- This jacket is dirty; it needs cleaned \\ b- If I had known, I would have went there. \\ c- That is difficult, but I might could do it.}

A total of 146 participants including teachers of English at the tertiary levels in both the Middle East and North America took part in this online survey. Participants working in the Middle East included teachers at a large public university in the Sultanate of Oman, working at a Language Center where most students entering the university are expected to study intensive English for one to two years prior to entering the colleges of their majors. A link to the questionnaire was emailed to all the faculty members at the Language Center, more than 200 in number. Of these, 53 responded to the email and filled out the instrument. Those participants working in North America included teachers of English - linguistics, language, and literature, at the tertiary level at various institutions of higher learning. The link to the questionnaire was mainly dispersed by posting it on the Facebook page of one of the researchers. The link was forward- 
ed to English teachers via Facebook. The distribution of the instrument to both sets of participants, therefore, ensured a random sample of participants. Table 1 below provides descriptive information about the participants.

As Table 1 shows, 105 of the participants have English as an L1. Non-English speakers have various L1s including Arabic, an Indian language, Italian, Russian, Danish, Afrikaans, Japanese, and Tagalog. Participants' educational qualifications include 65 participants with Ph.D. degrees and 81 with master's degrees in different English disciplines. With participants' specializations, the researchers chose to group Linguistics, Applied Linguistics and TESOL together, and Rhetoric and Composition and Literature together in order to answer one of the research questions. There are 54 teachers of TESOL/EFL/Linguistics and 92 teachers of Literature and Rhetoric and Composition.

Results

To answer the first research question about the participants' perception towards New English structures in a) their students' written work, their students' spoken academic work, and their own written academic work, the participants' acceptance percentages were calculated for each item as shown in Table 2.

As Table 2 below shows, in general, participants are more tolerant of New English structures in their students' spoken language than in their written language. In the majority of the 25 items, acceptability of these structures in students' work was remarkably low. By contrast, participants showed high tolerance of these structures in students' spoken language. What is interesting about the figures in Table 2, however, is that even when participants accept certain New English structures in their students' spoken or written English, most of them still said they would not use the structure in their own writing. For example, with item $2,48 \%$ of the participants said they would accept the structure in their students' written aca-

Table 1. Demographic description of participants

\begin{tabular}{|l|l|l|}
\hline \multirow{2}{*}{ Gender } & M & 48 \\
\hline \multirow{2}{*}{ Native Language } & F & 98 \\
\hline \multirow{2}{*}{ Educational Qualifications } & English & 105 \\
\hline \multirow{2}{*}{ Teaching Experience } & Other & 41 \\
\hline \multirow{2}{*}{ Specialization } & Ph.D. & 65 \\
\hline & Other & 81 \\
\hline & 10 years and more & 41 \\
\hline & Less than 10 years & 105 \\
\hline & TESOL/EFL/Linguistics & 54 \\
\hline & Literature, Rhetoric & 92 \\
\hline
\end{tabular}

demic English, 88\% said they would accept the same structure in their students' spoken academic English. When it came to using the structure in their writing, however, only $16 \%$ said they would use the structure in their own writing. In general, the data reveal that participants were not as willing to accept New Englishes norms in their classrooms as scholars of New Englishes want them to.

Table 2 also shows that participants' attitudes towards different items differed; in other words, their acceptance of different items was different. Investigating whether participants' attitudes towards certain New Englishes was greater than it was toward other New Englishes, however, was beyond the scope of this paper; this warrants further research.

The second research question attempts to explore if there were any differences between male and female participants in their responses to the different structures. To answer this research question the data were submitted to a t-test. As Table 3 shows that there are no significant differences between males and females'

Table 2. Participants' attitudes toward New English structures

\begin{tabular}{|l|c|c|c|c|c|c|}
\hline & \multicolumn{2}{|c|}{$\begin{array}{c}\text { Students' Aca- } \\
\text { demic }\end{array}$} & \multicolumn{2}{|c|}{$\begin{array}{c}\text { Students' } \\
\text { demic }\end{array}$} & Speech & \multicolumn{2}{|c|}{$\begin{array}{c}\text { Participants' Writ- } \\
\text { ten Work }\end{array}$} \\
\hline Item 1 & \% No & $\%$ Yes & $\%$ No & $\%$ Yes & $\%$ No \\
\hline Item 2 & 48 & 57 & 52 & 48 & 3 & 97 \\
\hline Item 3 & 7 & 93 & 43 & 57 & 1 & 99 \\
\hline Item 4 & 12 & 88 & 52 & 48 & 3 & 97 \\
\hline Item 5 & 50 & 50 & 84 & 16 & 23 & 77 \\
\hline Item 6 & 57 & 43 & 80 & 20 & 23 & 77 \\
\hline Item 7 & 24 & 76 & 62 & 38 & 6 & 94 \\
\hline Item 8 & 21 & 78 & 63 & 37 & 6 & 94 \\
\hline Item 9 & 14 & 86 & 49 & 51 & 3 & 97 \\
\hline Item 10 & 18 & 82 & 53 & 47 & 7 & 93 \\
\hline Item 11 & 6 & 94 & 36 & 64 & 1 & 99 \\
\hline Item 12 & 22 & 78 & 69 & 31 & 7 & 93 \\
\hline Item 13 & 12 & 88 & 47 & 53 & 3 & 97 \\
\hline Item 14 & 7 & 93 & 30 & 70 & 4 & 96 \\
\hline Item 15 & 8 & 92 & 40 & 60 & 2 & 98 \\
\hline Item 16 & 12 & 88 & 54 & 46 & 2 & 98 \\
\hline Item 17 & 38 & 62 & 76 & 24 & 7 & 93 \\
\hline Item 18 & 51 & 49 & 84 & 16 & 20 & 80 \\
\hline Item 19 & 21 & 79 & 64 & 36 & 4 & 96 \\
\hline Item 20 & 9 & 91 & 63 & 37 & 1 & 99 \\
\hline Item 21 & 25 & 75 & 62 & 38 & 4 & 96 \\
\hline Item 22 & 73 & 27 & 93 & 7 & 43 & 57 \\
\hline Item 23 & 50 & 50 & 71 & 29 & 21 & 79 \\
\hline Item 25 & 8 & 92 & 53 & 47 & 2 & 98 \\
\hline
\end{tabular}


attitudes towards New English structures in their students' spoken or written, or in their own work.

The third research question explores the relationship between the native language spoken by the participants (English vs. other) and their attitudes towards the different structures. A t-test was run to determine whether there were any differences between participants' perceptions of New English structures based on their own L1a. As is clear from Table 3 above, there are significant differences between native speakers and non-native speakers with regard to their acceptance of these sentences in student writing. English native speakers' mean is higher, which suggests that they are significantly more accepting of these structures in their students' writing than are non-native speakers. In other words, non-native speakers are stricter in terms of accepting these structures. The reason for this finding could be due to non-native speakers paying greater attention to traditional grammatical accuracy than native speakers, a point made by Want (2016) and Ren, Chen, and Lin (2016). However, before such a conclusion can be made definitively, further research with a greater sample size is needed.

The table also shows there are no significant differences between native and non-native teachers' acceptance of these structures in students' spoken English or in their own use of the structures. Despite absences of significance, the native speakers' means in both cases is higher than that of non-native speakers, which is consistent with our findings that nonnative speakers are less tolerant of these forms than non-native speakers.

The fourth research questions attempts to investigate the impact of the instructor's educational background (TESOL/Linguistics/EFL vs. Literature/Rhetoric) on their acceptability of the given constructions. Results of a t-test show that the teachers specialized in literature and rhetoric are significantly more accepting of the new English forms both in student writing and student speech, and the t-values show that the difference is significant at a $p$ of .05. This could be explained by the fact that literature and rhetoric faculty do not focus exclusively on grammar whereas the other group does, and is therefore less accepting of new norms. It is possible, therefore, to surmise that literature and rhetoric professionals focus more on content and not as much on grammar. The finding is interesting in light of the fact that, as mentioned earlier, scholars such as Milroy and Milroy (1985) claim that it is scholars of language, linguists, who are more tolerant of innovations in language. The current finding suggests that
Table 3. Variation in perception by gender

\begin{tabular}{|l|l|l|l|l|}
\hline & & Mean & t-value & p-value \\
\hline \multirow{2}{*}{ Student writing } & Male & .213 & & \\
& Female & .263 & & \\
\hline & Male & .607 & & \\
\hline Student speech & Female & .600 & .136 & .892 \\
\hline & Male & .068 & & \\
\hline Instructors & Female & .094 & .139 & .135 \\
\hline
\end{tabular}

Table 4. Variation in perception by language

\begin{tabular}{|c|c|c|c|c|}
\hline & & Mean & t-value & p-value \\
\hline \multirow{2}{*}{ Student writing } & English & .271 & \multirow{2}{*}{2.472} & \multirow{2}{*}{.016} \\
\hline & Other & .184 & & \\
\hline \multirow{2}{*}{ Student speech } & English & .615 & \multirow{2}{*}{.870} & \multirow{2}{*}{.387} \\
\hline & Other & .569 & & \\
\hline \multirow{2}{*}{ Instructors } & English & .093 & \multirow{2}{*}{1.728} & \multirow{2}{*}{.087} \\
\hline & Other & .065 & & \\
\hline
\end{tabular}

Table 5. Variation in perception by specialization

\begin{tabular}{|l|l|l|l|l|}
\hline & & Mean & t-value & $\begin{array}{c}p \text { - } \\
\text { value }\end{array}$ \\
\hline \multirow{2}{*}{ Student writing } & TESOL/Linguistics/EFL & .197 & & \\
\cline { 1 - 5 } & Literature and Rhetoric & .276 & -2.454 & .016 \\
\hline \multirow{2}{*}{ Student speech } & TESOL/Linguistics/EFL & .533 & & \\
\hline & Literature and Rhetoric & .643 & & .023 \\
\hline Instructors & TESOL/Linguistics/EFL & .071 & & \\
\hline & Literature and Rhetoric & .094 & & \\
\hline
\end{tabular}

this is not true. As mentioned earlier, however, before either of these conclusions can be reached, further research with a larger sample size is necessary.

The fifth research question examines whether years of experience has any impact on the respondents' perception of the given constructions. Results of a ttest show that there are no significant differences between more experienced and less experienced teachers in how they judge the acceptability of new English structures. In other words, both experienced teachers and less experienced teachers regarded New English structures in the same way, both in their students' language and in their own.

The last research question investigates whether the instructor's educational qualifications have any effect on their perception of New English structures. Results of a t-test, shown in Table 7, reveal that there are sig- 
nificant differences between those participants with Ph.D. degrees and those without in their acceptance of these forms in spoken and written student work, but not in their own work. The means of Ph.D. holders are higher both with student writing and speech. This suggests that participants with Ph.D. degrees are more accepting of New English structures than are those participants with lower degrees. It is possible that they are more cognizant of the issues of world languages and have had more reading in these areas, where participants with master's degrees in TESOL or linguistics focused on coursework that tended to be more methodological in nature.

\section{Discussion}

The results shown above reveal that modality (spoken vs. written) is a strong predictor of acceptability of the New English structures. Overall, the majority of the respondents were more tolerant of these constructions in students' academic spoken English but significantly less accepting of them in both students' writing and their own. This could be explained by the fact that the written forms are expected to be more formal than oral presentations. As such, the respondents' expect their students to use the recognized standards of writing based on the norms assumed in the Western norms. These results are in agreement with most register-based studies on New Englishes, which consistently show that innovations arise in spoken registers of the new varieties, with the written registers more closely resembling the traditional native varieties of English (Biber et al., 1999).

Perhaps most telling, however, is that even when participants were willing to accept certain structures in their students' English, they said they were unwilling to use the structures in their own English. Another interesting result was that teachers from non-English backgrounds were less willing to accept new English structures in their students' work than were the teachers from English backgrounds. A possible explanation of this finding is that non-English L1 teachers are more aware of the high stakes of their students producing "proper" English.

While the importance of the recognition of New Varieties of English is indisputable, what we question, however, particularly based on the current study, is whether we, scholars of language, are correct in our eagerness to teach such new English structures to our EFL students. Davies (2009: 80) pointed out that "At present, what seems to hold back the use of Western norms ... is less the hegemony of Western postcolo-
Table 6. Variation in perception by years of teaching experience

\begin{tabular}{|l|l|l|l|l|}
\hline & & Mean & t-value & p-value \\
\hline Student writing & Less than 10 years & .285 & & \\
\hline & 10 years and greater & .232 & & .1662 \\
\hline Student speech & Less than 10 years & .620 & & \\
\hline & 10 years and greater & .595 & & .611 \\
\hline Instructors & Less than 10 years & .096 & & \\
\hline & 10 years and greater & .081 & .750 & .456 \\
\hline
\end{tabular}

Table 7. Variation by educational qualifications

\begin{tabular}{|l|l|c|c|c|}
\hline \multirow{3}{*}{ Student writing } & & Mean & t-value & p-value \\
\hline & Ph.D. & .289 & & \\
\cline { 2 - 5 } & Other & .213 & 2.360 & .020 \\
\hline \multirow{2}{*}{ Student speech } & Ph.D. & .687 & & \\
\cline { 1 - 5 } & Other & .534 & 3.47 & .001 \\
\hline Instructors & Ph.D. & .102 & & \\
\hline & Other & .072 & 1.709 & .090 \\
\hline
\end{tabular}

nial and economic power and more the uncertainty of local stakeholders". Based on the results of the current study, the only thing that is clear is that New English features are not as acceptable as World English scholars such as Rajagopalan (2013) would want them to be. It is unclear whether the non-acceptance of the New English features among teaching professionals we surveyed is because of the teachers' personal lack of acceptance of such features, or because of their uncertainty of their acceptance in the international academic arena; as mentioned above, this was particularly true of teachers from non-English L1 backgrounds. If the latter situation were true, it would seem that Davies is right. Local stakeholders might be more comfortable presenting and teaching new English features in their language classrooms if they felt assured of their acceptance in the international academic arena. If, as Bolton, Graddol, and Meierkord (2011: 459) contend, "academics in developing countries have parallel difficulties in publishing research, both in journals and books with international publishers", how can we ELT professionals justify the teaching of New English norms in an EFL classroom? Wouldn't this make the EFL learnerss entrance into the international academic arena even more difficult?

This point has a lot of support from researchers from various parts of the world. Deumert et al., for exam- 
ple, state of South Africans, that "inadequate knowledge of the dominant social languages (English and Afrikaans) limits opportunities for employment and access to social services" (2005: 303). Michieka (2009) expresses similar views about rural Kenya. De Klerk (1999: 318) speaks strongly about attitudes of South Africans towards South African English: "Middle and upper-class black parents sent their children to formerly whites-only schools, where English is the medium of instruction, wishing that their children acquire (proper) English." She further goes on to explain that "with their privileged educational backgrounds, selite closures is likely to result from their influence in maintaining the normative value of exonormative English" (p. 318). Research on acceptables English in India is just as strong (Sonntag, 2003). Graddol is (2010) point that communication skills in English are becoming increasingly sought after by employers is one expressed by many researchers. Of the Philippines, Bernardo (2008: 36) comments that "the overwhelming majority of Filipino children find their limited proficiency in English a major stumbling block in their efforts to learn in the various domains of knowledge."

The important question that arises from all these New English settings, then, is what exactly is racceptables? This is exactly what New English research has focused on for several decades now, and World English scholars have for long cried for greater recognition and acceptance of New English grammars. However, whether the description of New English grammars will be anything other than an academic exercise (however fruitful in showing the constant evolution of English) remains to be seen. In the early nineties, Quirk (1990: 24) claimed that "the mass of ordinary native-English speakers have never lost their respect for Standard English, and it needs to be understood abroad, too.... that Standard English is alive and well, its existence and its value alike clearly recognized." Quirk went on to explain that if teachers advocated their students use of New English structures, then students who were (sliberally) permitted to think their (new variety) of English was acceptable, would be defenseless before the harsher but more realistic judgment of those with authority to employ or promote them" (p. 24). Sonntag (2003) described that in India, even spoken varieties of English had be de-Indianized for it to be acceptable in certain settings. Describing call center employees in India, she explained:

The young people...had first to be trained for months, by instructors and by tapes, to acquire a pleasant middle American (not an educated American) accent, and to learn basic American slang...so that if the exchange with the client in the United States becomes prolonged, they will not falter with the small talk, and have the means to continue to pass for Americans.

There is, then, a definite distance between the academic and the people whose daily lives are affected by the variety of English they use. As Bolton, Graddol, and Meierkord (2011) eloquently put it, "academic research on English worldwide has typically tended to focus overly on official accounts and elite contexts of use, and relatively little published research actually provides the space for accounts of the sociolinguistic realities of particular contexts from the points of view of the grassroots players themselves" (p. 473). Bhatia (2006: 398) expressed a similar sentiment when he explained that, "Most professional and institutional genres are relatively on the more conservative side, and hence are more constrained in terms of creativity and innovation, partly because there are gate-keeping mechanisms operating in most of these socially constructed genres."

\section{Conclusion}

What are the implications of studies such as the current study on research on New Englishes? Undoubtedly, a study such as this will contribute to the continued discussion on the place of New Englishes in the language classroom, particularly in EFL contexts. However, we'd like to conclude with Bolton's (2006: 263) summation of the problem: "Despite what may be the best intentions of Western practitioners to develop an unbiased or at least politically neutral applied linguistics at the level of theory as well as pedagogic principles, it is difficult to ignore the imbalance between the developed and the developing world in many of the contexts of English language teaching today." In other words, the solution to the hegemony of native speaker English is not as simple as the adoption of New English norms. Bolton goes on to say, accurately, that "Academics from these societies have parallel difficulties in finding a voice in major journals in the field (although notable exceptions include English Today and World Englishes), as well as in book production" (p. 263). In a similar vein, Holliday (2009: 21) argues that "Center Academics" have to be careful not to be seduced into thinking that they can solve the problems faced by the "Periphery to which they do not belong and cannot speak for." We conclude by asking, again, how realistic it is that we see any variety of an International English, with features such as those used in the current study's questionnaire, be- 
ing entirely accepted in the larger academic discourse community.

Limitations of the study and directions for future research

One of the limitations of the current study is the relatively small sample size. In future studies, it would be important to determine if the current results could be replicated with a larger sample of participants, including teaching practitioners from different parts of the world. Furthermore, it would be important to determine whether any particular variety of English is deemed more acceptable than any other variety. Given that the different varieties represented in the questionnaire had different numbers of items, it was not possible to determine with some statistical reliability the impact of the language variety on the participants' perception of the syntactic constructions. Future research should investigate this issue.

It is clear from this study that there is definitely a divide between scholars of New Englishes on the one hand, and teaching practitioners, on the other. Future research should also explore methods and criteria for teaching practitioners to distinguish between errors and varietal features, and thereby contribute to the discussion on the legitimacy of New Varieties of English in the language classroom.

\section{References}

Balasubramanian, C. (2009). Register Variation in Indian English. Amsterdam: John Benjamins.

Bansal, R. K. (1976). The Intelligibility of Indian English. Eric Document \# 108284.

Bakshi, R. K. (1991). Indian English. English Today 7 3(27), pp. 43-46.

Bauer, I. (1989). The verb have in New Zealand English. English World-Wide 10, pp. 69-83.

Baumgardner, R. (1996). Pakistani English: Acceptability and the norm. World Englishes. 14, pp. 261-271. Bernardo, A. (2008). English in Philippine education: solution or problem? In Lourdes M., Bautista, S. \& Bolton, K. (eds.). Philippine English: Linguistic and Literary Perspectives. Hong Kong: Hong Kong University Press.

Bhatia, V. (2006). Genres and styles in World Englishes. In Kachru, B., Kachru, Y. \& Nelson, C. The Hand- book of World Englishes. Oxford: Blackwell Publishing.

Bolton, K., Graddol, D. \& Meiercord, C. (2011). Toward developmental world Englishes World Englishes 30(4), pp. 459-480.

Bolton, K. (2006). World Englishes today. In Kachru, B., Kachru, Y. \& Nelson, C. (eds.). The Handbook of World Englishes. Oxford: Blackwell Publishing.

Canagarajah, S. (2013). Translingual Practice: Global Englishes and Cosmopolitan Relations. New York: Routledge.

Crystal, D. (2003). English as a Global Language. Cambridge: Cambridge University Press.

Davies, A. (2009). Assessing World Englishes. Annual Review of Applied Linguistics, 29, pp. 80-89.

De Klerk, V. (1999). Black South African English: where to from here? World Englishes, 18, pp. 311-324.

Deumert, A., Inder, B. \& Maitra, P. (2005). Language, informal networks, and social protection. Global Social Policy, 5, pp. 303-328.

Erling, E. J. (2005). The many names of English. English Today, 21(1). 40-47.

Gisborne, N. (2000). Relative clauses in Hong Kong English. World Englishes, 19, pp.

357-371.

Graddol, D. (2010). English Next India: The Future of English in India. London: British Council.

Grieve, J. (2015). Regional Variation in Written American English. Cambridge: Cambridge University Press.

Hamid, M. O. (2014). World Englishes in international proficiency tests. World Englishes, 33(2), pp. 263-277.

Holliday, A. (2009). English as a Lingua Franca, 'nonnative speakers,' and cosmopolitan realities. In Sharifian, F. (ed.). English as an International Language: Perspectives and Pedagogical Issues. Toronto: Multilingual Matters.

Hosali, P. (1991). Some syntactic and lexico-semantic features of an Indian variant of English. Central Insti- 
tute of English and Foreign Languages Bulletin, 3(1-2), pp. 65-83.

Hsu, T. (2016). Removing bias towards World Englishes: The development of a Rater Attitude Instrument using Indian English as a stimulus. Language Testing, 33(3), pp. 367-389.

Jenkins, J. (2015). Repositioning English and multilingualism in English as a Lingua Franca. English in Practice, 2(3), pp. 49-85.

Jenkins, J. (2003). World Englishes. New York: Routeledge.

Kachru, B. (1994). Englishization and contact linguistics. World Englishes, 13, pp. 135-154.

Kirkpatrick, A. (2010). The Routledge Handbook of World Englishes. London:

Routledge.

Lange, C. (2007). Letss face the music: The multilingual challenge. Annual Review of South Asian Languages and Linguistics. 95-103.

Martin, I. P. (2014). Philippine English revisited. World Englishes, 33(1), pp. 50-59.

McArthur, T. (1998). Guides to tomorrowss English. English Today, 14, pp. 21-26.

Melchers, G. \& Shaw, P. (2003). World Englishes: An Introduction. Oxford: Oxford University Press.

Mesthrie, R., Swann, J., Deumert, A. \& Leap, W. (2012). Introducing Sociolinguistics. Edinburgh: Edinburgh University Press.

Mesthrie, R. (1992). English in Language Shift: The History, Structure, and Sociolinguistics of South African Indian English. Johannesburg: Witwatersrand University Press.

Michieka, M. (2009). Expanding Circle within the Outer Circle: the rural Kisii. World Englishes, 28, pp. 352-364.

Milroy, J. \& Milroy, L. (1985). Authority in Language: Investigating Language Prescription and Standardization. London: Routledge.
Mukherjee, J. \& Schilk, M. (2009). Exploring variation and change in New Englishes: Looking into the International Corpus of English (ICE) and beyond. In Vevalainen T. \& Traugott E (eds.) The Oxford Handbook of the History of English. Oxford: Oxford University Press.

Mufwene, S. (1998). Native speaker, proficient speaker and norms. In Singh, R. (ed.). The Native Speaker: Multilingual Perspectives. New Delhi: Sage.

Quirk, R. (1990). Language varieties and standard language. JALT Journal, 11(1), pp. 14-25.

Rajagopalan, K. (2012). «World English > or «World Englishesı? Does it make any difference? International Journal of Applied Linguistics, 22(3), pp. 374-391.

Ren, W., Chen, Y. \& Lin, C. (2016). University students' perceptions of ELF in mainland China and Taiwan. System, 56, pp. 13-27.

Rushdie, S. (1982). The empire writes back with a vengeance. The Times, 3 July, 8.

Schilk, M. (2009). Structural Nativization in Indian English lexicogrammar. Amsterdam: John Benjamins.

Schneider, E. (2007). The World Englishes conference in Regensburg 2007 - a retrospective look. World Englishes: Problems, Properties, and Prospects: Selected Papers from the 13th IAWE Conference.

Schneider, E. (2009). Postcolonial English: Varieties Around the World. Cambridge: Cambridge University Press.

Schneider, E. (2003) The Dynamics of New Englishes: From identity construction to dialect birth. Language, 79(2), pp. 233-281.

Sedlatschedk, A. (2009). Contemporary Indian English: Variation and change. Amsterdam: John Benjamins. Seidelhofer, B. (2004). Research perspectives on teaching English as a Lingua Franca. Annual Review of Applied Linguistics, 24, pp. 209-239.

Sonntag, S. (2003). The World as India. Times Literary Supplement, June 13. Electronic edition: http://www. the-tls.co.uk/. 
Wang, Y. (2016). Native English speakers' authority in English. English Today, 125(32), pp. 35-40.

Williams, J. D. (2005). The Teacher's Grammar Book. London: Routledge.
Youssef, V. (1995). Tense-aspect in Tobogonian English: A dynamic transitional system. English World Wide, 16, pp. 195-213.

\section{APPENDIX A}

\section{QUESTIONNAIRE}

Dear Colleagues,

We are working on a project on the following subject:

How acceptable are certain syntactic constructions in students) CLASSROOM English, both spoken and written? With this in mind, could you please fill out this short questionnaire and let us know if you would accept the following sentences in your students ' a) written classroom English; b) spoken classroom English (i.e. a formal class presentation; excluding conversations (such as class discussions among students in class)?

Further, would you use any of the constructions in your own formal written English? I would be grateful if you could send the completed questionnaire to us at chandribala@gmail.com or radwan64@gmail.com Thank you very much for your time and cooperation!

Part One:

Some information about you:

1. Highest educational qualification:

2. Area of expertise/specialization:

3. Years of teaching experience:

4. What level/class do you teach?

5. What country and city do you teach in now?

6. Other countries you taught English in?

7. Your native language:

8. Nationality:

9. Gender: 
Part Two:

Please fill in the box using "Yes" if the construction is acceptable, or "No" if it is not.

\begin{tabular}{|c|c|c|c|c|}
\hline & Sentence & $\begin{array}{l}\text { Students } \\
\text { written } \\
\text { work }\end{array}$ & $\begin{array}{l}\text { Students } \\
\text { spoken } \\
\text { work }\end{array}$ & $\begin{array}{l}\text { Would you use them in your } \\
\text { own academic writing? }\end{array}$ \\
\hline 1 & This jacket is dirty; it needs cleaned. & & & \\
\hline 2 & But the grandsons, they know how to speak English. & & & \\
\hline 3 & He is going there, isnst it? & & & \\
\hline 4 & Although you are away, but you do not forget. & & & \\
\hline 5 & It is costing too much money. & & & \\
\hline 6 & I am having a pain in my stomach. & & & \\
\hline 7 & I have been there last year. & & & \\
\hline 8 & It has lot of layers. & & & \\
\hline 9 & That is difficult, but I might could do it. & & & \\
\hline 10 & If I had known, I would have went there. & & & \\
\hline 11 & The guests what you invited are not here yet. & & & \\
\hline 12 & Do you know what will she say? & & & \\
\hline 13 & If I had the doing of it again, I'd do it different. & & & \\
\hline 14 & I was knowing your face. & & & \\
\hline 15 & That's one of the related problem we will be discuss. & & & \\
\hline 16 & I didnst do nothing. & & & \\
\hline 17 & $\begin{array}{l}\text { But a survey done by Pulse Asia shows majority of } \\
\text { their respondents want President Estrada. }\end{array}$ & & & \\
\hline 18 & The ring of my fiancée was expensive. & & & \\
\hline 19 & One of the lecturer told me to see you. & & & \\
\hline 20 & What you doing on weekend? Want to go out? & & & \\
\hline 21 & We got in our bikes and rode down the hill. & & & \\
\hline 22 & I have seen you already. & & & \\
\hline 23 & Problems are there with every party. & & & \\
\hline 24 & $\begin{array}{l}\text { It's a good environment, good friends, and good } \\
\text { environment also. }\end{array}$ & & & \\
\hline 25 & $\begin{array}{l}\text { He has parked wrongly. He has parked straight before } \\
\text { I came. }\end{array}$ & & & \\
\hline
\end{tabular}

Any additional comments: 